Maja Fosner

Faculty of logistics, University of Maribor

e-mail: maja.fosner@um.si

Sonja Mlaker Kač

Faculty of logistics, University of Maribor

e-mail: sonja.mlaker@um.si

\title{
HOW MATURE ARE COMPETENCIES IN SLOVENE LOGISTICS SECTOR? AN OVERVIEW OF THE COMPETENCE MATURITY AND PLANS FOR THE FUTURE
}

\begin{abstract}
The goal of the article is to present logistics competence maturity model and place Slovenia with its logistics development according to this model. Competencies can in general be describes as skills, knowledge and abilities needed for successful work (in our case in logistics). We will present the Slovene study system of logistics (Faculty of logistics), Slovenian logistics association and development of logistics competencies in Slovenia in general.

In the end we will according to our own research try to place Slovenia into competence maturity matrix.
\end{abstract}

Key words: Competence, logistics, competence maturity matrix

\section{INTRODUCTION}

The aim of this article is to present the skills, competencies and knowledge needed for successful work in logistics and supply chains. We will present logistics competence maturity matrix. Slovene logistics sector was not included in this research, so we will present results from different researches in competencies in logistics in Slovenia. Based on our own research we will try to fit Slovenia and Slovene logistics sector in this map of competence development.

\section{COMPETENCIES}

Fosner M., Mlaker Kač S., How Mature Are Competencies in Slovene Logistics Sector? An Overview of the Competence Maturity and Plans for the Future [in:] Adamczak M. et al., Digitalization of Supply Chains, Spatium, Radom 2019, p. 152-159. https://doi.org/10.17270/B.M.978-83-66017-86-3.11 
Competencies can be in general described as "capability or ability" (Boyatzis, 1982, McClelland, 1973). The behavioural approach describe competencies as a "set of related but different sets of behaviour organized around an underlying construct called the intent" (Boyatzis, 2011).

Kohont $(2005,33)$ describes competencies as "a whole of interrelated skills, knowledge, motivation, self-image and values that an individual knows, wants and is able to successfully use in a given work situation".

\section{COMPETENCIES IN LOGISTICS IN SLOVENIA}

Several researches in field of competencies in logistics in Slovenia have been conducted in last years. Slovene companies expect from logistics experts following competencies (Mlaker Kač and Fošner, 2016):

- "good analytical thinking;

- good communication skills;

- good knowledge of foreign languages (in most cases English, in many cases also German or Croatian);

- good negotiation skills;

- accuracy;

- good in quick learning and willingness to learn;

- innovativeness;

- good in working with many information and databases;

- good in reporting the results,

- flexibility;

- quick in decision making;

- good leading skills;

- good in supervision and control;

- good in organizing work and co-workers;

- good general planning skills.

- knowledge of legal filed connected to logistics;

- knowledge of competition in their field;

Fosner M., Mlaker Kač S., How Mature Are Competencies in Slovene Logistics Sector? An Overview of the Competence Maturity and Plans for the Future [in:] Adamczak M. et al., Digitalization of Supply Chains, Spatium, Radom 2019, p. 152-159.

https://doi.org/10.17270/B.M.978-83-66017-86-3.11 
- good knowledge of outsourcing activities and their providers;

- good knowledge of warehousing;

- good selling and consulting skills in logistics and supply chain management;

- knowledge of managing logistics costs;

- good knowledge of specific documents related to logistics (for example documents related to purchase orders, delivery notes and invoices);

- knowledge and understanding of different logistics techniques and technologies."

\section{STUDY PROGRAMMES OF FACULTY OF LOGISTICS AND INTERNATIONAL ACCREDITATION}

Faculty of Logistics University of Maribor is the only specialised faculty in this field and »aims to encourage and inspire students, employees and the broader public to study logistics in greater depth, as an interdisciplinary and multidisciplinary discipline. Our aim is also to promote logistics in Slovenia and abroad through the pursuit of education, science and research « (Faculty of Logistics, Mission, vision, strategic guidelines).

Special emphasis is on:

- »facilitating co-operation and collaboration with partner institutions,

- designing contemporary and interactive study programmes,

- facilitating personal and professional development of an individual,

- integrating theoretical and practical knowledge,

- developing strategic research,

- facilitating diversity and experience,

- finding sustainable, reliable and professional solutions,

- keeping track of and co-operating in standardisation and legislation projects.« (Faculty of Logistics, Mission, vision, strategic guidelines).

Faculty of logistics University of Maribor also makes a positive influence on (Faculty of Logistics, Mission, vision, strategic guidelines)

Fosner M., Mlaker Kač S., How Mature Are Competencies in Slovene Logistics Sector? An Overview of the Competence Maturity and Plans for the Future [in:] Adamczak M. et al., Digitalization of Supply Chains, Spatium, Radom 2019, p. 152-159. https://doi.org/10.17270/B.M.978-83-66017-86-3.11 
- $\quad$ the students - by implementing quality full-time and part-time studies and life-long learning and integrating research work,

- employees - by providing a safe and pleasant work environment and promoting personal and professional development,

- the users of our services - employers of our graduates will be more successful when developing and offering efficient logistics services and products,

- the broader social environment - by developing new knowledge being socially responsible in all activities.«

Strategic guidelines of Faculty of Logistic University of Maribor are: "providing continuous quality in all areas of education and research, keeping the leading role in the broader regional area, integrating into international education and research networks, facilitating research activities, developing new study programmes, implementing e-learning and videoconferencing, creating a student-friendly environment, establishing new education centres at home and abroad, managing human resources, building a strong organizational culture" (Faculty of Logistics, Mission, vision, strategic guidelines).

Study programmes (Professional degree programme, University degree programme and Master's degree programme) of Faculty of Logistics University of Maribor are accredited by ECBE, the European Council for Business Education, and ACBSP, Accreditation Council for Business Schools and programmes.

ECBE is an international not-for-profit educational organisation, registered in Brussels as an AISBL - Association Internationale Sans But Lucrative. It is committed to supporting academic and professional learning institutions in business and related fields. It provides advice and consulting services to encourage and support institutions to commit themselves to continuous improvement by engaging in its accreditation processes. It also creates valuable networking opportunities for schools interested in internationalising their curriculum and contacts. These services help to enhance the learning environment and career opportunities for students of business. (European Council for Business Education).

ACBSP's accreditation process follows the Baldrige model. The accreditation focuses on recognizing teaching excellence, determining student learning outcomes, and a continuous

Fosner M., Mlaker Kač S., How Mature Are Competencies in Slovene Logistics Sector? An Overview of the Competence Maturity and Plans for the Future [in:] Adamczak M. et al., Digitalization of Supply Chains, Spatium, Radom 2019, p. 152-159. https://doi.org/10.17270/B.M.978-83-66017-86-3.11 
improvement model. ACBSP's student-centred teaching and learning approach, which is measured and analysed for quality, ensures that students gain the right skills from their educational investment. Institutions with programs accredited by ACBSP are committed to continuous improvement that ensures their business program will give students the skills employers want. (Accreditation Council for Business Schools \& Programs)

According to these two accreditation Faculty of logistics is better recognized all over the world and follows educational standards prescribed by the international accreditation houses. Therefore, Faculty of logistics annually updates our study programmes and put modern contents in the curriculum according to trends in Logistics.

\section{SLOVENE LOGISTICS ASSOCIATION}

Slovenian Logistic Association is »free, independent and non-profit organisation of members and supporters« (Slovenian Logistic Association, Introduction).

Main goal of association is "professional acting and networking on the field of transportation, traffic and business logistics. Association connects experts, entrepreneurs, managers and other people, who act in this field and want to contribute to the development of transportation, traffic and business logistics« (Slovenian Logistic Association, Introduction). Expected benefits of membership at Slovenian Logistic Association are: »networking, experience exchange, best practices, fair visiting, less expensive access to best professional events, friendship, professional training, access to top experts" (Slovenian Logistic Association, Expected benefits of membership).

The main goals of education and trainings that are provided by Slovenian Logistics Association are »to share knowledge among SLZ members through workshops, presentations, trainings and exchange of different experiences from practice. Through such events organisation would like to raise awareness about quality of logistics services within SLZ members and external experts. Organization would also like to include other organizations and experts to support the exchange of knowledge ideas among members« (Slovenian Logistic Association, Education and trainings).

Fosner M., Mlaker Kač S., How Mature Are Competencies in Slovene Logistics Sector? An Overview of the Competence Maturity and Plans for the Future [in:] Adamczak M. et al., Digitalization of Supply Chains, Spatium, Radom 2019, p. 152-159. https://doi.org/10.17270/B.M.978-83-66017-86-3.11 
Key activities in area of education and training are: presentations, workshops, general and professional courses, trainings, best practice share and fair visits. (Slovenian Logistic Association, Education and trainings).

\section{LOGISTIC COMPETENCE MATURITY MATRIX}

Logistics competence maturity matrix presents stakeholder guideline for logistics competence development. Countries are divided into three different groups: basic logistics competencies maturity, intermediate logistics competence maturity and advanced logistics competence maturity. Details are explained in Figure 1.

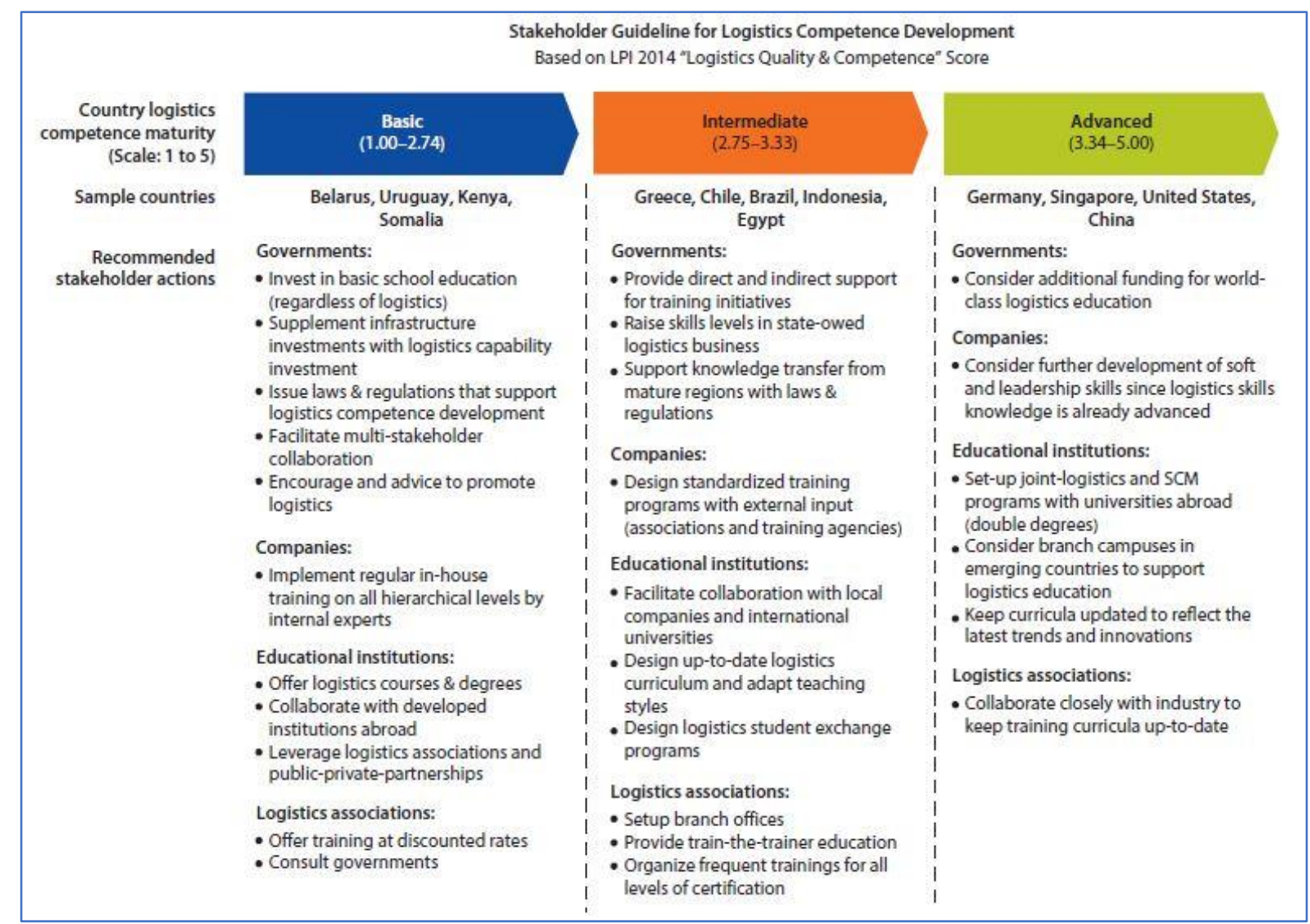

Fig. 1: Logistics Competence Maturity Matrix.

Source: McKinnon, Flothmann, Hoberg \& Busch, 2017, p. 68

Fosner M., Mlaker Kač S., How Mature Are Competencies in Slovene Logistics Sector? An Overview of the Competence Maturity and Plans for the Future [in:] Adamczak M. et al., Digitalization of Supply Chains, Spatium, Radom 2019, p. 152-159.

https://doi.org/10.17270/B.M.978-83-66017-86-3.11 
Slovenia has not been included into research. But from our own research presented in this article we can claim that Slovenia is very well developed in logistics competency maturity (we would place it at the beginning stage of the advanced level).

Logistics sector is increasing rapidly in Slovenia and logistics companies are developing very quickly.

Slovenia has a good bologna study system, programmes at Faculty of logistics are modern, well developed and internationally accredited (ECBE and ASBSP accreditations).

Slovenian logistics association is also well developed. They organise different education and training programmes and conferences where partners and companies can improve and develop their logistics business ideas.

\section{CONCLUSION}

This article presents short theoretical background of competencies and competencies in logistics. Furthermore we discussed the development of logistics competencies in Slovenia and the importance and contribution of Faculty of logistics University of Maribor and Slovenian Logistics Association to well-developed field of logistics competencies.

The future plans are mostly connected to improvement of cooperation between all stakeholders: especially companies with core business in logistics sector, Faculty of logistics and Slovenian Logistics Association. All stakeholders together and their cooperation in projects, education and training programme can lead to better logistics competencies.

\section{REFERENCES}

Accreditation Council for Business Schools \& Program. Available at: https://www.acbsp.org/ Boyatzis, R. E. (1982). The Competent Manager: A Model of Effective Performance, John Wiley \& Sons, New York.

Boyatzis, R. E. (2011). Managerial and Leadership Competencies: A Behavioral Approach to

Emontional, Social and Cognitive Intelligence. Vision, 15 (2), 91-100.

European Council for Business Education. Available at: http://ecbe.eu/

Faculty of Logistics, Mission, vision, strategic guidelines. Available at: http://fl.um.si/about/simple-facts/9883-2/?lang=en

Fosner M., Mlaker Kač S., How Mature Are Competencies in Slovene Logistics Sector? An Overview of the Competence Maturity and Plans for the Future [in:] Adamczak M. et al., Digitalization of Supply Chains, Spatium, Radom 2019, p. 152-159. https://doi.org/10.17270/B.M.978-83-66017-86-3.11 
Kohont, A. (2005). Razvrščanje kompetenc. In M. S. Pezdirc (Ed.), Kompetence v kadrovski praksi (pp. 29-49). Ljubljana, Slovenia: GV Izobraževanje..

Mlaker Kač, S, Fošner, M. (2016). Qualitative research of expected competencies in logistics. In: Draskovič, V.. Management and logistics: selected topics. 1st electronic ed. Czestochowa [etc.]: SPH - Scientific Publishing Hub. 77-83.

McClelland, D.C. (1973). Testing for competence rather than intelligence. American Psychologist, 28 (1), 1-40.

McKinnon, A., Flothmann, C., Hoberg, K \& Busch (2017). Logistics Competencies, Skills and Training. Washington: The World Bank.

Slovenian Logistic Association, Introduction. Available at: http://www.slz.si/en/introduction$\underline{\text { sla/introduction-of-sla }}$

Slovenian Logistic Association, Expected benefits of membership. Available at: http://www.slz.si/en/home/item/199-expected-benefits-of-membership

Slovenian Logistic Association, Education and trainings. Available at: http://www.slz.si/en/areas-of-interest/education-and-trainings.

Fosner M., Mlaker Kač S., How Mature Are Competencies in Slovene Logistics Sector? An Overview of the Competence Maturity and Plans for the Future [in:] Adamczak M. et al., Digitalization of Supply Chains, Spatium, Radom 2019, p. 152-159. 